\title{
Effectuation or causation: An fsQCA analysis of entrepreneurial passion, risk perception, and self-efficacy
}

\author{
Silvia Stroe ${ }^{\mathrm{a}, *}$, Vinit Parida ${ }^{\mathrm{b}, \mathrm{c}}$, Joakim Wincent ${ }^{\mathrm{b}, \mathrm{d}}$ \\ ${ }^{a}$ Politecnico di Milano, Department of Management, Economics and Industrial Engineering, Via Lambruschini 4/b, 20156 Milan, Italy \\ ${ }^{\mathbf{b}}$ Luleå University of Technology, Entrepreneurship and Innovation, SE-971 87 Luleå, Sweden \\ ${ }^{\mathrm{c}}$ University of Vaasa, Department of Management, Vaasa, Finland \\ ${ }^{\mathrm{d}}$ Hanken School of Economics, Entrepreneurship and Management, Arkadiagatan 22, P.O.Box 479, FI-00100 Helsinki, Finland
}

\begin{abstract}
This paper enriches the literature on entrepreneurial decision-making logic by investigating nascent en-trepreneurs' use of effectuation and causation. The configurational effect of passion, entrepreneurial self-efficacy, and risk perception is tested for causal and effectual decision-making. The results, based on data gathered from 50 nascent entrepreneurs, show that, more than passion, entrepreneurial self-efficacy, and risk perception alone, it is their combination that leads to the use of a causal and an effectual logic. This fsQCA-based study thereby helps unravel some of the complexities behind entrepreneurs' choice of decision-making logic.
\end{abstract}

\section{Introduction and relevance of the topic}

In recent decades, the number of entrepreneurship studies has grown considerably. This genuine interest in entrepreneurship is understandable. Not only does entrepreneurship offer a viable solution to current economic turbulence by creating jobs and bringing about progress in struggling economies (Read \& Sarasvathy, 2005; Sarasvathy, 2001), but it also reflects the rise of the entrepreneurial society phenomenon. Thus, entrepreneurial values such as creativity, proactiveness, and grit have transcended the domain of new business venturing and have become appreciated and promoted in all types of jobs and ventures (Audretsch, 2009; Martin \& Osberg, 2007). Regardless of the context, entrepreneurial action requires the entrepreneur to make decisions under conditions of high uncertainty against a rapidly changing backdrop (McMullen \& Shepherd, 2006; Sarasvathy, 2001).

In her seminal work, Sarasvathy (2001) distinguished between decision-making logics that focus on prediction and those that focus on non-predictive control. Prediction can have an essential function in goaldirected pursuit: If individuals can predict the future, they can control outcomes and are thereby more likely to experience success. The predictive decision-making logic, also called causation (Sarasvathy, 2001, 2008), refers to pursuing success with the help of estimates and analyses that make accurate factual predictions of expected future outcomes. Predictive strategies such as causation include forecasting scenarios, estimating consequences, and formulating refined portfolio strategies by considering various alternatives (Wiltbank, Read, Dew, \&
Sarasvathy, 2009). With causation, the assumption is that one can gain control over outcomes by predicting the venture context and by placing the venture in a favorable position for future success.

In a complex and uncertain setting such as the entrepreneurial context, however, predictions are less accurate and useful (Dew, Read, Sarasvathy, \& Wiltbank, 2009; Read, Song, \& Smit, 2009). Forecasting becomes increasingly complex, so decision makers may benefit from employing decision logics that reduce the need for prediction (Axelrod \& Cohen, 1999; March, 2006). Effectuation offers just such an ap-proach. Effectuation is a framework of non-predictive control and builds upon the assumption that one does not need to forecast the future if one can control future developments (Sarasvathy, 2001). In ambiguous contexts, non-predictive control may be more advantageous than predictive methods. Effectuation refers to a framework of intern-ally coherent heuristic principles that focus on developing and con-trolling solutions to uncertainty. Effectual principles emphasize the resources in the individual's possession rather than pre-set goals for the future (Perry, Chandler, \& Markova, 2012; Sarasvathy, 2001, 2008). In contrast, in causal decision-making logic, goals are highly emphasized, and the objective is to find and gather the resources required to attain these goals.

The logic of effectuation was detected while studying expert entrepreneurs, who seemed to sidestep prediction when handling the uncertainty that is intrinsic in developing new ventures (Sarasvathy, 2008). Because novice entrepreneurs, who lack business creation experience, were assumed to prefer the use of predictive decision-making

\footnotetext{
* Corresponding author.

E-mail addresses: ioanasilvia.stroe@polimi.it (S. Stroe), vinit.parida@ltu.se (V. Parida), joakim.wincent@ltu.se (J. Wincent).
} 
logics such as causation, the main supposition in interpreting Sarasvathy's findings was that greater expertise in venture creation substantially changes how entrepreneurs make decisions (Dew et al., 2009; Read et al., 2009). Therefore, in recent years, entrepreneurial expertise has become the backbone of effectual decision-making theory (Sarasvathy, 2001). Nonetheless, this assumption was never directly tested, and emerging research has questioned the sole reliance on experience-based explanations (Baron, 2009). Recent studies report the use of effectuation by nascent entrepreneurs too (e.g., Chandler, DeTienne, McKelvie, \& Mumford, 2011; Engel, Dimitrova, Khapova, \& Elfring, 2014), but theory still fails to explain why and under which conditions nascent entrepreneurs apply an effectual decision-making logic. Moreover, despite the rapidly growing number of studies devoted to entrepreneurs' choice of effectuation or causation (Perry et al., 2012; Read et al., 2009; Read, Sarasvathy, Dew, \& Wiltbank, 2016), research on the determinants of the use of effectuation and causation remains limited in scope. Because effectuation and causation have different effects on the structure and functioning of new ventures (Sarasvathy, 2001, 2008), their innovativeness (Brettel, Mauer, Engelen, \& Küpper, 2012; Frese, 2014), and their success (Read et al., 2009), a better understanding of the determinants of these two decision-making strategies is needed.

In this study, the baseline for studying the antecedents of causation and effectuation logics consists of certain prominent individual-level variables from the entrepreneurship literature. These variables are passion, entrepreneurial self-efficacy, and risk perceptions. Although these variables have been shown to affect a variety of entrepreneurial outcomes (Baum \& Locke, 2004; Chen, Greene, \& Crick, 1998; Simon, Houghton, \& Aquino, 2000) and have been cited as factors that affect general entrepreneurial decision-making (Cardon, Wincent, Singh, \& Drnovsek, 2009; Hmieleski \& Baron, 2008; McMullen \& Shepherd, 2006), they have been overlooked in previous effectuation studies.

Effectuation was introduced as a theory of entrepreneurial expertise (Sarasvathy \& Dew, 2008). In our study, however, we consider entrepreneurs' decision-making choices to be less closely linked to specific competencies and resources of the entrepreneur. Instead, we assume that the way entrepreneurs think and behave relates more to their affective preferences and cognitive evaluations of the self and the environment (Bandura, 1997; Baron, 2008). Indeed, individuals orient to situations and decide how to pursue goals based on beliefs (Schoenfeld, 2011). Individual-level variables such as passion, entrepreneurial selfefficacy, and risk perception are psychological constructs that are central to our understanding of entrepreneurial drive and behavior and, by extension, entrepreneurial decision-making (Boyd \& Vozikis, 1994; Cardon et al., 2009; Mitchell et al., 2002; Simon et al., 2000). These psychological factors might explain preferences for a predictive versus non-predictive decision-making process. Moreover, these characteristic factors can be attributed to both nascent, and experienced entrepreneurs. Therefore, studying these factors can advance our knowledge of entrepreneurs' choice of effectuation versus causation beyond the explanatory power of a theory of entrepreneurial experience.

\section{Theoretical framework and research propositions}

\subsection{Entrepreneurship as a research setting}

Entrepreneurship research has progressed considerably in terms of a body of empirical evidence, and has thus become a legitimate scholarly research domain (Bygrave \& Hofer, 1991). Nevertheless, the terms entrepreneurship and entrepreneur have been ascribed numerous definitions. The most widely used definitions of these terms define entrepreneurship as the processes of opportunity discovery and exploitation and entrepreneurs as the individuals who discover, evaluate, and exploit opportunities (Shane \& Venkataraman, 2000). This study adheres to this definition of entrepreneurship as a process of new venture creation (Bygrave \& Hofer, 1991; Hitt, Ireland, Sirmon, \& Trahms,
2011; Shane \& Venkataraman, 2000; Timmons \& Spinelli, 2003), and focuses on early-stage entrepreneurial phenomena such as nascent entrepreneurship.

Actively involved in starting new ventures, nascent entrepreneurs are entrepreneurs who have initiated serious activities that are intended to result in an operable organization (Aldrich \& Ruef, 2006; Reynolds et al., 2005). Their intention is not merely to engage in opportunity exploration, but rather to make tangible progress toward starting a new venture. Nevertheless, their ventures are not yet in operation. Because this study addresses the antecedents of different decision-making logics beyond entrepreneurial expertise, we positioned our research in the context of nascent entrepreneurship. In this study, the term nascent entrepreneur refers exclusively to novice entrepreneurs-that is, entrepreneurs who lack substantial entrepreneurial experience (Davidsson \& Honig, 2003).

\subsection{Causation and effectuation}

In an effort to disentangle entrepreneurial decision-making, researchers have conceptualized two main decision-making strategies: causation and effectuation. Causal decision-making relies on systematic processing modes and consists of predictions based on existing information. Effectual logic is a set of rationales alternative to causation, oriented toward on action and control (Read \& Sarasvathy, 2005; Sarasvathy, 2001; Sarasvathy \& Dew, 2005; Wiltbank, Dew, Read, \& Sarasvathy, 2006). Causal, predictive framing refers to discovering and exploiting current opportunities in a prearranged problem space, whereas effectual, non-predictive logic focuses on rearranging the problem space and restructuring current realities into new opportunities (Wiltbank et al., 2006). Causal and effectual decision-making logics differ in terms of various heuristic principles that are applied in the new venture creation process.

First, the two logics differ regarding the basis for making decisions and taking action. Under causation, a specific goal is viewed as being fixed, and the focus is on choosing the right way to attain that goal. Under causal or predictive logic, entrepreneurs set a goal and then plan how to achieve that goal. The planning involves analyzing various dimensions of the environment such as competitors, the market, and their competitive advantage and positioning (Brinckmann, Grichnik, \& Kapsa, 2010). Entrepreneurs elaborate a tactical blueprint and gather the necessary means to attain the goal (Sarasvathy, 2008). In contrast, an effectual process starts from the entrepreneur's resources, and fo-cuses on increasing and optimizing performance using these resources (Sarasvathy, 2001; Sarasvathy \& Dew, 2005).

Second, causal and effectual logics differ in terms of the way entrepreneurs react to unexpected events and deal with the market context and challenges. Under causation, entrepreneurs aspire to implement an initial strategic plan and respond negatively to unforeseeable events, which are considered obstacles to executing the plan (Sarasvathy, 2001). Effectuation, on the other hand, is an adaptive process whereby entrepreneurs seek out and incorporate external feedback. This flexibility allows effectual decision-makers to use unforeseen events to the emerging firm's advantage (Chandler et al., 2011).

Third, causal and effectual decision-making strategies differ in terms of how the entrepreneur perceives, interrelates with, and includes other stakeholders in the creation and development of the nascent venture. Entrepreneurs who adopt a causal framework are competitor oriented, focus on building their competitive advantage, and protect their venture's know-how from outsiders. They develop partnerships based on complementary competencies that help them achieve their goals, and they set clear guidelines for these partnerships (Read et al., 2009). In contrast, not only are entrepreneurs that adopt an effectual logic open to the participation of committed stakeholders, but they are also contingent on these stakeholders' contribution. These stakeholders supply and offer their own resources, co-creating the firm's 
development and emerging goals. They thereby reduce uncertainty for entrepreneurs (Read et al., 2009). Furthermore, effectual entrepreneurs are open about their product development efforts. For example, they reveal their products to potential customers in the hope of receiving helpful feedback.

Lastly, causal and effectual entrepreneurs have different approaches regarding resources and risk and the volume and flexibility of their investments. Because causal entrepreneurs are guided by a clear plan, they usually require major investments in their new venture so that expected returns can be maximized. In contrast, effectual entrepreneurs embrace the intrinsic ambiguity of the entrepreneurial context and follow a principle of affordable loss (Read \& Sarasvathy, 2005). For entrepreneurs who adopt an effectual logic, the focus is not on high investments that maximize potential future returns, but rather on available resources and small investments to ensure that the new venture does not suffer if these investments are lost (Dew et al., 2009).

\subsection{Passion as a determinant of effectuation and causation}

Passion is an intense, positive feeling toward venture activities, and it develops as a reaction to a distant but desired state of the venture (Cardon et al., 2009; Cardon, Wincent, Singh, \& Drnovsek, 2005; Vallerand, 2008). Passion's strong motivational force derives from the evaluation of the future venture outcome as highly significant for the entrepreneur's well-being (Cardon et al., 2005). Therefore, passion will likely influence the choice of the decision-making logic supposed to guide the entrepreneur toward achieving the highly significant venture outcome. To explore passion's effect on the entrepreneur's choice of decision-making logic, two distinct types of passion must be considered. These types of passion are harmonious and obsessive passion, which have different characteristics and produce different outcomes for the entrepreneur.

Harmoniously passionate entrepreneurs engage in entrepreneurial activity because they derive pleasure from this activity and not because of external or internal pressures (Lafrenière, Bélanger, Sedikides, \& Vallerand, 2011; Ryan \& Deci, 2000). Therefore, harmonious passion is characterized by process-focused motivation, whereby entrepreneurs are more likely to focus on the venture activity itself and on improving their performance, rather than on outcomes and goals (Pham \& Taylor, 1999; Vallerand et al., 2007). As a result of the integrative self-processes that are at play, harmoniously passionate entrepreneurs have a sense of control over their venture activity, are flexible in their goal pursuit (Vallerand et al., 2003), and are open to new experiences and experimentation (Hodgins \& Knee, 2002). Because of this flexibility, harmoniously passionate entrepreneurs are more likely to embrace the unexpected in their decision-making and work together with internal and external partners to develop the venture. Furthermore, because harmonious passion leads to positive affective experiences (Mageau, Vallerand, Rousseau, Ratelle, \& Provencher, 2005; Vallerand et al., 2003), harmoniously passionate entrepreneurs are more likely to adopt a heuristic processing strategy such as effectuation (Isen, 1987).

Proposition 1. High values of harmonious passion in entrepreneurs result in the use of effectuation.

Obsessively passionate entrepreneurs, in contrast, engage in entrepreneurship because of interpersonal or intra-personal pressures such as boosting self-esteem or feeling socially accepted or superior (Vallerand et al., 2003). Accordingly, obsessive passion is characterized by an outcome-focused motivation whereby entrepreneurs are constantly preoccupied with achieving planned goals rather than focusing on the venture-related task itself (Pham \& Taylor, 1999; Vallerand, 2010). Therefore, they are more likely to be goal driven and to plan and envision desired entrepreneurial outcomes (Lafrenière et al., 2011; Vallerand et al., 2003). Obsessively passionate entrepreneurs have been shown to set performance goals for themselves-that is, to be competitor oriented and focus on beating rivals or try to prevent failure relative to others (Vallerand et al., 2007). Furthermore, obsessively passionate entrepreneurs try to avoid and anticipate the unexpected (Vallerand, 2010), have a rigid view of goal attainment, and do not feel in control of the venture activity (Vallerand et al., 2003). Therefore, they will be likely to rigidly follow initial goals and plans and persist until they achieve these goals (Cardon et al., 2009). Because of their defensive engagement in the venture activity, obsessively passionate entrepreneurs will experience distress and negative affect while engaging in the entrepreneurial activity (Vallerand et al., 2003). Therefore, they are more likely to adopt a systematic processing strategy such as causation (Schwarz \& Clore, 1996).

Proposition 2. High values of obsessive passion in entrepreneurs result in the use of causation.

\subsection{Entrepreneurial self-efficacy as a determinant of effectuation and causation}

Entrepreneurial self-efficacy reflects how strongly entrepreneurs perceive that they are able to successfully attain goals associated with the new venture (Bandura, 1991; Chen et al., 1998). Since entrepreneurial decisions are often attributed to (over-)confidence in ability (Hayward, Shepherd, \& Griffin, 2006; Koellinger, Minniti, \& Schade, 2007), entrepreneurial self-efficacy is an important antecedent in decision-making (Mauer, Neergaard, \& Linstad, 2017). Entrepreneurial self-efficacy offers the level of confidence required for entrepreneurs to expect success in attaining the venture's goals (Boyd \& Vozikis, 1994). Such a perception might also make entrepreneurs believe that they can foretell the outcomes of their venture activities (Bandura, 1997), thereby leading them to adopt a causal decision process. Indeed, self-efficacious entrepreneurs are more likely to focus on the future and construct or visualize success scenarios that guide their actions (Gollwitzer, 1999; Wood \& Bandura, 1989). Therefore, highly self-efficacious entrepreneurs are expected to be more committed to planning than entrepreneurs with lower self-efficacy (Bandura, 1997; Luszczynska, Scholz, \& Schwarzer, 2005). Moreover, highly selfefficacious entrepreneurs will set clear, challenging goals, monitor themselves, spend considerable effort in goal attainment, and commit more strongly to these goals than entrepreneurs with low self-efficacy (Bandura, 1997; Gollwitzer, 1999). Indeed, perceived self-ef-ficacy is considered a crucial part of practical managerial techniques such as goal-setting and performance feedback (Locke, Frederick, Lee, \& Bobko, 1984).

Proposition 3. High values of entrepreneurial self-efficacy result in the use of causation.

Conversely, entrepreneurial self-efficacy can also stimulate heuristic thinking and enhance entrepreneurs' self-belief in being able to shape the environment (Busenitz \& Barney, 1997; Wood \& Bandura, 1989). Self-efficacious entrepreneurs focus on opportunities in the environment (Bandura, 1997; Engel et al., 2014) and are therefore likely to consider unexpected events as a source of opportunity (Sarasvathy, 2008). Since entrepreneurial self-efficacy triggers the same mechanisms through which effectuation functions (such as proactiveness, agency, and control), entrepreneurial self-efficacy is likely to prompt non-predictive, effectual decision processes (Sarasvathy \& Dew, 2008).

Proposition 4. High values of entrepreneurial self-efficacy result in the use of effectuation.

\subsection{Risk perception as a determinant of effectuation}

Variation in risk perception-that is, the way a person evaluates chance and probability (Krueger \& Dickson, 1994)—is a critical factor in the choice between predictive or non-predictive decision-making logic (Ghosh \& Ray, 1992; Sarasvathy, 2008). How entrepreneurs 
respond in a decision context depends on how they interpret signals from the environment. The perception of a risky environment lowers the entrepreneur's perceived ability to control the outcomes of behavior (Giordano Martínez, Herrero Crespo, \& Fernández-Laviada, 2017; Jackson \& Dutton, 1988), which in turn lowers the utility of setting fixed goals, following plans, and making big investments. Instead, high perceived risk encourages entrepreneurs to use a non-predictive decision-making logic, where the focus is on managing the process rather than outcomes. Perceiving the environment as risky makes entrepreneurs carefully weigh up their next moves, push the venture forward in small steps while considering how the context will develop (Sitkin \& Weingart, 1995), and seek support and pre-commitments from partners to counter this risk (Read et al., 2009b).

Proposition 5. High values of risk perception of the entrepreneurs result in the use of effectuation.

\section{Method}

\subsection{Sample}

This study focuses on the use of causation and effectuation by nascent entrepreneurs without entrepreneurial expertise, so we gathered the data accordingly. Nascent entrepreneurs are hard to identify. Data on nascent entrepreneurs are difficult to procure from conventional sources such as business directories because nascent entrepreneurs' ventures are not yet registered (Honig \& Samuelsson, 2012). Although they have received little scholarly attention in the past (Ross \& Byrd, 2011), events such as new venture emergence workshops and competitions are beginning to be recognized by entrepreneurship scholars as a launch pad for nascent entrepreneurs. Such events are therefore a valuable source of data on nascent entrepreneurs (Fishback, Gulbranson, Litan, Mitchell, \& Porzig, 2007; Ross \& Byrd, 2011). To build a sample exclusively comprising nascent entrepreneurs, we contacted a major entrepreneurship foundation in Germany. This foundation organizes an annual start-up competition that admits only first-time entrepreneurs who are active in early-stage ventures. Using this source helped us avoid survival bias and capture all nascent ventures, regardless of whether they failed or whether the entrepreneurs abandoned the venture later. We were thus able to form a more complete picture of nascent entrepreneurs. Moreover, this data gathering design excluded latent nascent entrepreneurs (Reynolds et al., 2005), who merely intend to engage in opportunity exploitation but who have made no tangible progress toward starting a new venture. The design also omitted new ventures that are already in operation.

We contacted the entrepreneurs of the 328 participating ventures through the event organizer's weekly newsletter and invited the entrepreneurs to complete our online survey. We incentivized survey participation by offering the chance to win one of three entrepreneurship tool books. Prior to administering the survey, we pilot-tested the questionnaire with three doctoral researchers, the event organizers, and two entrepreneurs. Respondents had no difficulty answering any of the pilot survey instrument's items, so we proceeded to administer the selfreport questionnaire. We received responses from 76 entrepreneurs, representing a $23.1 \%$ response rate. Of these responses, 24 were incomplete and two had unacceptably low reliability, indicating that the respondent had not taken the survey seriously. After these 26 responses had been removed, the final sample comprised 50 entrepreneurs. On average, respondents were 34 years old, $74 \%$ were male, and $76 \%$ had a university degree.

\subsection{Measures}

As previously stated, we measured causation and effectuation following Chandler et al.'s (2011) procedure. For causation, sample items included the following: "We organized and implemented control processes to make sure we met objectives" and "We researched and selected target markets and did meaningful competitive analysis." Cronbach's alpha for the seven causation items was 0.85 . Following Chandler et al.'s (2011) procedure, we treated effectuation as a formative construct with the following subscales: flexibility, affordable loss, experimentation, and pre-commitment. Each subscale had several items (Chandler et al., 2011; Frese, 2014). Items for flexibility included "We were flexible and took advantage of opportunities as they arose." A sample item for the experimentation sub-dimension was "The product/ service that we now provide is substantially different from how we first imagined it." The Cronbach's alphas for each variable were acceptable, considering the nature of the construct (ranging from 0.65 for the four experimentation items to 0.84 for the four pre-commitment items), and comparable to those reported in previous research (Chandler et al., 2011; Dew, Read, Sarasvathy, \& Wiltbank, 2015; Harms \& Schiele, 2012). The items used to measure effectuation and causation were scored on a five-point Likert scale that ranged from 1 (completely disagree) to 5 (completely agree). Harmonious and obsessive forms of passion were measured using the dualistic model of passion scale (Vallerand et al., 2003). Sample items for harmonious passion included "My role as an entrepreneur is in harmony with the other activities in my life" and "Being an entrepreneur is in harmony with other things that are part of me." Items measuring obsessive passion included "Being an entrepreneur is so exciting that I sometimes lose control over it" and "I have the impression that my role as an entrepreneur controls me." The items were rated on a five-point Likert scale ranging from 1 (completely disagree) to 5 (completely agree). Both scales had acceptable internal consistency: Cronbach's alphas were 0.77 and 0.79 for har-monious and obsessive passion, respectively. For entrepreneurial self-efficacy, we used 15 items from Chen et al. (1998), as adapted by Forbes (2005) and applied by Cardon and Kirk (2015). These 15 items were rated using a five-point Likert scale ranging from 1 (completely disagree) to 5 (completely agree). The question was formulated as "Please indicate the degree of certainty you have in your ability to perform the following tasks." Sample items were "establish and achieve goals and objectives" and "make decisions under risk and uncertainty." The measure had good internal consistency: Cronbach's alpha was 0.86 . Risk perception was measured using a seven-item scale devised by Podoynitsyna, Van der Bij, and Song (2012). Cronbach's alpha was 0.76. The question was "How would you characterize the challenges (e.g., threats from new competitors, volatile markets and technologies, and rapidly changing customer preferences) that you encounter in your new venture?" Sample items were "as opportunities" (reversed) and "as threats." Items were rated on a five-point Likert scale ranging from 1 (completely disagree) to 5 (completely agree).

\subsection{The fsQCA method}

We analyzed the data using fuzzy-set qualitative comparative analysis (fsQCA), a set-theoretic analysis method that closely examines how configurations of causal conditions contribute to a specific outcome (Fiss, 2007). FsQCA offers a configurational approach to investigating the way determinants interact to produce an outcome. The technique can handle substantial causal complexity (Ragin, 2000, 2008) and is effective with small samples. FsQCA identifies patterns of causal conditions that produce the outcome, rather than focusing on how one individual independent variable relates to the outcome.

\subsection{Calibration of variables}

FsQCA was used to investigate the relationship between causal conditions (harmonious passion, obsessive passion, entrepreneurial selfefficacy, and risk perception) and the outcome decision-making logic (i.e. effectuation vs. causation). The software used for the analysis was fsQCA 3.0 (Ragin \& Davey, 2014). Ideally, original scaled values should be transformed into fuzzy-set membership scores for all 
Table 1

Analysis of necessary conditions for the presence of causation and effectuation.

\begin{tabular}{llllll}
\hline \multirow{2}{*}{ Conditions } & \multicolumn{2}{l}{ Outcome } & & \\
\cline { 2 - 3 } & \multicolumn{2}{l}{ Causation } & & \multicolumn{2}{l}{ Effectuation } \\
\cline { 2 - 3 } \cline { 5 - 6 } & Consistency & Coverage & & Consistency & \multirow{2}{*}{ Coverage } \\
\hline Harmonious passion & 0.679707 & 0.687192 & 0.794626 & 0.678242 \\
$\sim$ Harmonious passion & 0.568864 & 0.514990 & 0.494220 & 0.377725 \\
Obsessive passion & 0.590993 & 0.605343 & 0.585260 & 0.506097 \\
$\sim$ Obsessive passion & 0.592030 & 0.529817 & 0.610738 & 0.461426 \\
Self-efficacy & 0.732676 & 0.808157 & 0.721196 & 0.671587 \\
$\sim$ Self-efficacy & 0.544945 & 0.459049 & 0.525687 & 0.373852 \\
Risk perception & 0.513928 & 0.575978 & 0.540116 & 0.511042 \\
$\sim$ Risk perception & 0.660351 & 0.549629 & 0.654971 & 0.460237 \\
\hline
\end{tabular}

conditions and outcomes based on substantive, theoretical knowledge (Ragin, 2008). For this purpose, Ragin (2008) proposed the direct method of calibration. This method consists of defining three qualitative anchors: the threshold for full non-membership, the crossover point, and the threshold for full membership. To generate these an-chors, we used the 10th, 50th, and 90th percentiles, respectively (López-Cabarcos, Vázquez-Rodríguez, \& Piñeiro-Chousa, 2016; Misangyi \& Acharya, 2014).

\section{Key findings}

\subsection{Analysis of necessity}

An initial round of analysis in fsQCA was conducted to evaluate whether the causal conditions were necessary for the outcome to occur (analysis of necessity). As is customary in fsQCA analyses, the assessment of causal necessity was based on a consistency threshold of 0.9 (Schneider, Schulze-Bentrop, \& Paunescu, 2010). Table 1 illustrates the results of the causal necessity analysis. Notably, no causal condition was necessary for either causation or effectuation because the con-sistency score did not exceed the threshold of 0.9 for any condition. Therefore, the results of the analysis of necessity do not support any of the propositions.

\subsection{Analysis of sufficiency}

After the necessity analysis, the next step is to identify combinations (configurations) of conditions that are causally sufficient for the outcomes of presence of effectuation and causation to occur. We therefore performed sufficiency analysis with the help of the truth table. In this study, the assessment of causal sufficiency was based a frequency threshold of 1 and a consistency threshold of 0.75 . The frequency threshold indicates that only configurations with at least one case are empirically pertinent (Fiss, 2007). The consistency threshold indicates the extent to which membership in the outcome set is systematically higher than or equal to membership in a particular causal configuration set.

Table 2 displays the results of the sufficiency analysis and shows the degree of association between configurations and the presence of causation or effectuation. These solutions include all logical remainders that are theoretically consistent with the presence of the outcomes (Ragin, 2008). The analysis revealed two casual configurations for the presence of causation and three causal configuration for the presence of effectuation. Measures of consistency and coverage are displayed for the overall solutions and for each individual configuration in Table 2. Coverage refers to the extent to which the solutions explain all cases of presence of effectuation and causation. The coverage score ranges from 0 to 1 (Ragin, 2008). The coverage of the overall solution was 0.80 for the presence of causation and 0.70 for the presence of effectuation. These coverage scores demonstrate the coverage of a considerable share
Table 2

Analysis of sufficient conditions for the presence of causation and effectuation.

\begin{tabular}{|c|c|c|c|c|c|}
\hline \multirow[t]{3}{*}{ Conditions } & \multicolumn{5}{|c|}{ Outcome } \\
\hline & \multicolumn{2}{|c|}{ Causation } & \multicolumn{3}{|c|}{ Effectuation } \\
\hline & IA & IIA & IB & IIB & IIIB \\
\hline Harmonious passion & & & $\bullet$ & $\bullet$ & \\
\hline Obsessive passion & & $\bullet$ & & & 0 \\
\hline Entrepreneurial self-efficacy & $\bullet$ & & $\bullet$ & & $\bullet$ \\
\hline Risk perception & & 0 & & - & 0 \\
\hline Consistency & 0.80 & 0.66 & 0.82 & 0.78 & 0.82 \\
\hline Raw coverage & 0.73 & 0.37 & 0.58 & 0.43 & 0.27 \\
\hline Unique coverage & 0.43 & 0.07 & 0.22 & 0.07 & 0.04 \\
\hline Overall solution consistency & 0.72 & & 0.77 & & \\
\hline Overall solution coverage & 0.80 & & 0.70 & & \\
\hline
\end{tabular}

Note: Black circles $(\bullet)$ indicate the presence of a condition, and unfilled circles $(O)$ indicate the absence of a condition.

of the sample. The five individual configurations had consistency scores ranging from 0.66 to 0.82 , implying their sufficiency for the presence of the outcome.

A higher coverage score reflects a better empirical explanation of the outcome (Ragin, 2008). Therefore, Table 2 ranks the configurations by raw coverage. To explain the configurations, the character "**" de-notes the logical operator AND, and the character " " denotes the condition's absence (e.g., low level of self-efficacy).

For the presence of causation, configuration IA (ese) implies that entrepreneurial self-efficacy (i.e., the belief that one is capable of achieving the venture's goals) is a sufficient (though not necessary) condition for the entrepreneur to choose a predictive, goal-focused causal decision-making logic. Second, configuration IIA (op $* \sim r p$ ) implies that a high level of obsessive passion leads entrepreneurs to adopt a causal decision-making logic when the lack of perceived risks justifies this choice.

For the presence of effectuation, harmonious passion alone is not a sufficient condition, but it does play an important role. Configuration IB ( $h p * e s e)$ implies that entrepreneurs who experience harmonious passion and are self-efficacious eschew causal decision-making logic in favor of effectual logic. Configuration IIB $(h p * r p)$ implies that when entrepreneurs perceive risk in the environment, harmonious passion is needed to justify the choice of an effectual, non-predictive decision process. Configuration IIIB (ese $* r p * \sim o p$ ) implies that self-efficacious entrepreneurs who perceive risks for the venture need to not be obsessively passionate in order to acknowledge the benefits of adopting a non-predictive decision-making logic.

\section{Discussion, limitations, and contributions}

\subsection{Discussion}

This study explores when and under what circumstances individual entrepreneurs' passion, entrepreneurial self-efficacy, and risk perception lead to a causal or effectual decision-making logic. Empirical analysis was conducted using fsQCA, a comparative analysis method that investigates relationships between a set of causal conditions and an outcome. This method is particularly suitable for studying decisionmaking logics because individuals weight in many different evaluations concomitantly when engaging in decision-making. Our empirical analysis reveals the role of individual affective and cognitive evaluations in the choice of either effectuation or causation, thereby increasing our knowledge of nascent entrepreneurial decision-making.

According to our results, no antecedent condition alone is necessary to produce the outcome. However, several causal configurations are sufficient for the presence of causal or effectual decision processes.

First, the solution suggests that the presence of entrepreneurial self- 
efficacy is sufficient for entrepreneurs to use causation. A reason for that might be the fact that entrepreneurs' perception of their ability to perform entrepreneurial tasks increases their perceived control and allows them to engage in predictive decision strategies. This finding is consistent with previous studies that identified a preference among selfefficacious entrepreneurs for predictive decision-making (Boyd \& Vozikis, 1994; Gollwitzer, 1999; Wood \& Bandura, 1989). Second, causation also seems to be used by obsessively passionate entrepreneurs who do not perceive risk in the environment. Proposition 2 posits that obsessively passionate entrepreneurs are likely to engage in causal decision processes. However, our results imply that for obsessively passionate entrepreneurs to adopt a predictive decision-making style, they need to perceive causal decision-making as appropriate because of low perceived risk in the environment. This finding suggests that passionate entrepreneurs not only heed gut feelings in their decision processes, but also apply reason (e.g., evaluating the environment). Accordingly, this finding supports the view of passion as a "consciously accessible" feeling (Cardon et al., 2009, p. 517).

In the case of effectuation, harmonious passion seems to function as a balancing force in the entrepreneurs' choice of decision-making style. Harmonious passion alone is not sufficient for the use of effectuation, but it is central to the use of effectuation. This finding is consistent with previous studies that have reported passion's role in coordinating cognition and behavior (e.g., Cardon et al., 2009; Cardon \& Kirk, 2015; Ma \& Tan, 2006). Our results show that their harmonious passion seems to steer self-efficacious entrepreneurs away from using a causal decisionmaking logic, and toward the choice of an effectual decision process. This finding supports previous studies that have underlined harmoniously passionate entrepreneurs' preference for flexible, process-oriented engagement in venture activities (Klaukien, Shepherd, \& Patzelt, 2013; Lafrenière et al., 2011; Thorgren \& Wincent, 2013; Vallerand et al., 2003). Contradicting Proposition 5, the results imply that the perception of risk alone is not sufficient to steer entrepreneurs toward a non-predictive decision process. When the environment is perceived as risky, harmonious passion is needed to make entrepreneurs aware of the advantages of non-predictive decision-making logic such as effectuation. This finding supports previous studies that have shown that harmonious passion facilitates adaptive cognitive processes (Forest, Mageau, Sarrazin, \& Morin, 2011; Vallerand, 2010). Lastly, entrepreneurial self-efficacy and the perception of risk seem to lead to effectuation when obsessive passion is absent. This finding allows us to assume that, in order to be able to deploy effectuation when positive evaluation of their entrepreneurial capabilities and perceptions of risk in the environment demand it, entrepreneurs need not experience obsessive passion. Although our study fails to prove that the presence of obsessive passion alone is sufficient for entrepreneurs to choose causation, not experiencing obsessive passion does seem to allow entrepreneurs to use effectuation, assuming other conditions are met.

The results of this study indicate that different individual-level factors interact to influence an entrepreneur's choice of decision-making logic. Considering both types of passion-harmonious and ob-sessiveseems important to understand an entrepreneur's choice of decisionmaking logic. Because of their different motivational foci-process versus outcome- the two types of passion seem to guide en-trepreneurs in their choice of decision-making logic. Specifically, har-monious passion seems to be an important, though not necessary, condition for effectuation.

\subsection{Limitations and future research}

This research has certain limitations. First, the sample consisted of German nascent entrepreneurs. Thus, further research is needed to replicate these findings for different geographical or cultural settings and for different types of entrepreneurs. Second, it would be interesting to evaluate whether the causal configurations found in this study remain static over time. Our study focuses on affective and perceptual individual antecedents of decision-making logic. Further research on the antecedents of effectuation and causation should consider addi-tional individual-level variables such as personality traits or motiva-tional constructs. Studies could also investigate team-level variables such as team conflict or team cooperativeness (Reuber, Fischer, \& Coviello, 2016). Finally, previous studies of the antecedents of effec-tuation and causation in different contexts (da Costa \& Brettel, 2011; Johansson \& McKelvie, 2012) have relied almost exclusively on mul-tiple regression analysis. Complementary studies employing QCA could uncover further combinations of individual-level or team-level factors that lead to predictive versus non-predictive decision logics. Further-more, a possible extension of this paper can include a test for predictive validity of the results.

\subsection{Contributions}

This study contributes to the effectuation literature by proposing and testing individual-level predictors of effectual and causal decision processes. The study thereby answers calls to identify the determinants of these two decision-making logics (Chandler et al., 2011; Reuber et al., 2016). Although in conformity with previous research on the topic, this study offers additional insights into the individual-level factors, besides expertise, that influence the choice of decision-making logic (Sarasvathy, 2008). The effectuation literature has been men-tioning the role of individual-level variables in the deployment of ef-fectuation (Goel \& Karri, 2006; Sarasvathy \& Dew, 2008). Thus far, however, the discussion has failed to indicate which individual dis-positional and cognitive differences drive effectuation-based logic (Mitchell et al., 2007). This study takes a first step toward responding to this question.

Second, this paper contributes to the decision-making literature by showing the utility of fsQCA in studies of decision-making logic, thereby providing fresh insight in this domain. Although early em-pirical studies of effectuation were generally qualitative and experi-mental (Sarasvathy, 1998), later empirical studies quantitatively mod-eled and tested effectuation and causation using multiple regression analysis with large samples (Brettel et al., 2012; Chandler et al., 2011; Harms \& Schiele, 2012). However, multiple regression analysis might not be the best method to investigate decision-making logics because it can only prove the presence of monotonically increasing and decreasing relationships between two variables. These net effects do not capture all features of reality because exclusively negative or positive relations between variables are not supported by all cases in any dataset (Woodside, 2013). This trouble with net effects is even more impairing when studying decision-making processes, since people weight in many different evaluations at the same time when engaging in decisionmaking. Therefore, fsQCA, which examines combinations of causal relations rather than independent effects, can offer deeper insight into how decisions are made. Using fsQCA, this study presents causal recipes with high membership scores in the two outcome conditions (i.e., effectuation and causation).

From a practical perspective, entrepreneurs and the institutions that coach and support them (e.g., incubators, government agencies, and investors) might benefit from an awareness that decision-making mechanisms depend on individual-level characteristics of the entrepreneur. By examining an entrepreneur's passion and internal and external perceptions, coaches and consultants can identify which decision-making style the entrepreneur is naturally inclined to choose. Because successful new venture creation is likely to need the implementation of both causal and effectual decision-making strategies (Berends, Jelinek, Reymen, \& Stultiëns, 2014; Sitoh, Pan, \& Yu, 2014), entrepreneurs who are prone to use effectuation (or causation) can get training to integrate causation (or effectuation) into their decisionmaking strategies. If entrepreneurs wish to flexibly employ decisionmaking logics depending on the situation they face, they might need to look inside themselves, consider their self-perceptions and perceptions of the environment, and assess their emotional bonds with the emerging venture. 


\section{Conclusions}

Given scholars' and practitioners' widespread interest in entrepreneurship and entrepreneurial decision-making strategies, our aim was to investigate individual-level determinants of entrepreneurs' choice of causation or effectuation. This study builds on recent research showing that effectual decision processes are used not only experienced entrepreneurs, but also inexperienced entrepreneurs (Chandler et al., 2011; Engel et al., 2014), and sheds light on the individual-level factors, besides expertise, that might affect he choice of decision-making logic.

This study illustrates the potential of configurational perspectives to enhance our understanding of the antecedents of decision-making logics. Our results suggest that, given the complexity of decision-making, scholars might gain a better understanding of entrepreneurs' use of causation or effectuation by replacing linear measurement models consisting of relationships between two variables with models consisting of causal configurations and an outcome. This study shows that to achieve a better understanding of the individual psychological factors that affect entrepreneurial decision-making, established concepts must be theorized and studied in new ways.

\section{References}

Aldrich, H. E., \& Ruef, M. (2006). Organizations evolving (2nd ed.). Thousand Oaks, CA: Sage.

Audretsch, D. B. (2009). The entrepreneurial society. The Journal of Technology Transfer, 34(3), 245-254.

Axelrod, R., \& Cohen, M. D. (1999). Harnessing complexity. Organizational implications of a scientific frontier. New York: Free Press/Simon \& Schuster.

Bandura, A. (1991). Social cognitive theory of self-regulation. Organizational Behavior and Human Decision Processes, 50(2), 248-287.

Bandura, A. (1997). Self-efficacy: The exercise of control. New York: Freeman.

Baron, R. A. (2008). The role of affect in the entrepreneurial process. Academy of Management Review, 33(2), 328-340.

Baron, R. A. (2009). Effectual versus predictive logics in entrepreneurial decision-making Differences between experts and novices: Does experience in starting new ventures change the way entrepreneurs think? Perhaps, but for now. Journal of Business Venturing, 24, 310-315.

Baum, J. R., \& Locke, E. A. (2004). The relationship of entrepreneurial traits, skill, and motivation to subsequent venture growth. Journal of Applied Psychology, 89(4), 587-598.

Berends, H., Jelinek, M., Reymen, I., \& Stultiëns, R. (2014). Product innovation processes in small firms: Combining entrepreneurial effectuation and managerial causation. Journal of Product Innovation Management, 31(3), 616-635.

Boyd, N. G., \& Vozikis, G. S. (1994). The influence of self-efficacy on the development of entrepreneurial intentions and actions. Entrepreneurship Theory and Practice, 18 63-63.

Brettel, M., Mauer, R., Engelen, A., \& Küpper, D. (2012). Corporate effectuation: Entrepreneurial action and its impact on R\&D project performance. Journal of Business Venturing, 27, 167-184.

Brinckmann, J., Grichnik, D., \& Kapsa, D. (2010). Should entrepreneurs plan or just storm the castle? A meta-analysis on contextual factors impacting the business planning-performance relationship in small firms. Journal of Business Venturing, 25(1), 24-40.

Busenitz, L. W., \& Barney, J. B. (1997). Differences between entrepreneurs and managers in large organizations: Biases and heuristics in strategic decision-making. Journal of Business Venturing, 12(1), 9-30.

Bygrave, W. D., \& Hofer, C. W. (1991). Theorizing about entrepreneurship. Entrepreneurship Theory and Practice, 16(2), 13-22.

Cardon, M. S., \& Kirk, C. P. (2015). Entrepreneurial passion as mediator of the self-efficacy to persistence relationship. Entrepreneurship Theory and Practice, 39(5), 10271050.

Cardon, M. S., Wincent, J., Singh, J., \& Drnovsek, M. (2005). Entrepreneurial passion: The nature of emotions in entrepreneurship. Academy of Management Proceedings, August 1, 2005. 1. Academy of Management Proceedings, August 1, 2005 (pp. G1-G6).

Cardon, M. S., Wincent, J., Singh, J., \& Drnovsek, M. (2009). The nature and experience

of entrepreneurial passion. Academy of Management Review, 34(3), 511-532. Chandler, G. N., DeTienne, D. R., McKelvie, A., \& Mumford, T. V. (2011). Causation and effectuation processes: A validation study. Journal of Business Venturing, 26, 375-390. Chen, C. C., Greene, P. G., \& Crick, A. (1998). Does entrepreneurial self-efficacy distinguish entrepreneurs from managers? Journal of Business Venturing, 13, 295-316.

da Costa, A. F. \& Brettel, M. (2011). Employee effectuation-what makes corporate employees act like entrepreneurs? Frontiers of Entrepreneurship Research, 31(17), 2.

Davidsson, P., \& Honig, B. (2003). The role of social and human capital among nascent entrepreneurs. Journal of Business Venturing 18(3), 301-331.

Dew, N., Read, S., Sarasvathy, S., \& Wiltbank, R. (2009). Effectual versus predictive logics in entrepreneurial decision-making: Differences between experts and novices. Journal of Business Venturing, 24, 287-309.

Dew, N., Read, S., Sarasvathy, S. D., \& Wiltbank, R. (2015). Entrepreneurial expertise and the use of control. Journal of Business Venturing Insights, 4, 30-37.

Engel, Y., Dimitrova, N. G., Khapova, S. N., \& Elfring, T. (2014). Uncertain but able: Entrepreneurial self-efficacy and novices' use of expert decision-logic under uncertainty. Journal of Business Venturing Insights, 1, 12-17.

Fishback, B., Gulbranson, C., Litan, R., Mitchell, L., \& Porzig, M. (2007). Finding business "idols": A new model to accelerate start-ups. The Ewing Marion Kauffman Foundation, Report, 4. Available at: http://ssrn.com/abstract $=1001926$.

Fiss, P. C. (2007). A set-theoretic approach to organizational configurations. Academy of Management Review, 32(4), 1180-1198.

Forbes, D. P. (2005). The effects of strategic decision-making on entrepreneurial selfefficacy. Entrepreneurship Theory and Practice, 29(5), 599-626.

Forest, J., Mageau, G. A., Sarrazin, C., \& Morin, E. M. (2011). "Work is my passion": The different affective, behavioural, and cognitive consequences of harmonious and obsessive passion toward work. Canadian Journal of Administrative Sciences/Revue Canadienne des Sciences de l'Administration, 28(1), 27-40.

Frese, T. (2014). Entscheidungsfindung in jungen Unternehmen: eine empirische Untersuchung der Anwendung von Entscheidungslogiken. Berlin-Heidelberg: Springer-Verlag.

Ghosh, D., \& Ray, M. R. (1992). Risk attitude, ambiguity tolerance and decision-making: An exploratory investigation. Decision Sciences, 23(2), 431-444.

Giordano Martínez, K. R., Herrero Crespo, Á., \& Fernández-Laviada, A. (2017). Influence of perceived risk on entrepreneurial desirability and feasibility: Multidimensional approach for nascent entrepreneurs. Journal of Risk Research, 20(2), 218-236.

Goel, S., \& Karri, R. (2006). Entrepreneurs, effectual logic, and over-trust. Entrepreneurship Theory and Practice, 30(4), 477-493.

Gollwitzer, P. M. (1999). Implementation intentions: Strong effects of simple plans. American Psychologist, 54, 493-503.

Harms, R., \& Schiele, H. (2012). Antecedents and consequences of effectuation and causation in the international new venture creation process. Journal of International Entrepreneurship, 10(2), 95-116.

Hayward, M. L., Shepherd, D. A., \& Griffin, D. (2006). A hubris theory of entrepreneurship. Management Science, 52(2), 160-172.

Hitt, M. A., Ireland, R. D., Sirmon, D. G., \& Trahms, C. A. (2011). Strategic entrepreneurship: Creating value for individuals, organizations, and society. The Academy of Management Perspectives, 25(2), 57-75.

Hmieleski, K. M., \& Baron, R. A. (2008). When does entrepreneurial self-efficacy enhance versus reduce firm performance? Strategic Entrepreneurship Journal, 2(1), 57-72. Hodgins, H. S., \& Knee, C. R. (2002). The integrating self and conscious experience. In E. L. Deci, \& R. M. Ryan (Eds.). Handbook of self-determination research (pp. 87-100). Rochester, NY: University of Rochester Press.

Honig, B., \& Samuelsson, M. (2012). Planning and the entrepreneur: A longitudinal examination of nascent entrepreneurs in Sweden. Journal of Small Business Management, 50(3), 365-388.

Isen, A. M. (1987). Positive affect, cognitive processes, and social behavior. Advances in Experimental Social Psychology, 20, 203-253.

Jackson, S. E., \& Dutton, J. E. (1988). Discerning threats and opportunities. Administrative Science Quarterly, 370-387.

Johansson, A., \& McKelvie, A. (2012). Unpacking the antecedents of effectuation and causation in a corporate context. Frontiers of Entrepreneurship Research, 32(17), 1.

Klaukien, A., Shepherd, D. A., \& Patzelt, H. (2013). Passion for work, nonwork-related excitement, and innovation managers' decision to exploit new product opportunities. Journal of Product Innovation Management, 30(3), 574-588.

Koellinger, P., Minniti, M., \& Schade, C. (2007). "I think I can, I think I can": Overconfidence and entrepreneurial behavior. Journal of Economic Psychology, 28(4), 502-527.

Krueger, N., \& Dickson, P. R. (1994). How believing in ourselves increases risk taking: Perceived self-efficacy and opportunity recognition. Decision Sciences, 25(3), 385-400.

Lafrenière, M. A. K., Bélanger, J. J., Sedikides, C., \& Vallerand, R. J. (2011). Self-esteem and passion for activities. Personality and Individual Differences, 51(4), 541-544. Locke, E. A., Frederick, E., Lee, C., \& Bobko, P. (1984). Effect of self-efficacy, goals, and task strategies on task performance. Journal of Applied Psychology, 69(2), 241-251.

López-Cabarcos, M.Á., Vázquez-Rodríguez, P., \& Piñeiro-Chousa, J. R. (2016). Combined antecedents of prison employees' affective commitment using fsQCA. Journal of Business Research, 69(11), 5534-5539.

Luszczynska, A., Scholz, U., \& Schwarzer, R. (2005). The general self-efficacy scale: Multicultural validation studies. The Journal of Psychology, 139(5), 439-457.

Ma, H., \& Tan, J. (2006). Key components and implications of entrepreneurship: A 4-P framework. Journal of Business Venturing, 21(5), 704-725.

Mageau, G. A., Vallerand, R. J., Rousseau, F. L., Ratelle, C. F., \& Provencher, P. J. (2005). Passion and gambling: Investigating the divergent affective and cognitive consequences of gambling. Journal of Applied Social Psychology, 35, 100-118.

March, J. G. (2006). Rationality, foolishness and adaptive intelligence. Strategic Management Journal, 27, 201-214.

Martin, R. L., \& Osberg, S. (2007). Social entrepreneurship: The case for definition. Vol. 5 Stanford: Stanford social innovation review28-39 (No. 2).

Mauer, R., Neergaard, H., \& Linstad, A. K. (2017). Self-efficacy: Conditioning the entrepreneurial mindset. Revisiting the entrepreneurial mind (pp. 293-317). Cham: Springer.

McMullen, J. S., \& Shepherd, D. A. (2006). Entrepreneurial action and the role of uncertainty in the theory of the entrepreneur. Academy of Management Review, 31(1), 132-152.

Misangyi, V. F., \& Acharya, A. G. (2014). Substitutes or complements? A configurational examination of corporate governance mechanisms. Academy of Management Journal, 
57(6), 1681-1705.

Mitchell, R. K., Busenitz, L., Lant, T., McDougall, P. P., Morse, E. A., \& Smith, J. B. (2002). Toward a theory of entrepreneurial cognition: Rethinking the people side of entrepreneurship research. Entrepreneurship Theory and Practice, 27(2), 93-104.

Mitchell, R. K., Busenitz, L. W., Bird, B., Gaglio, C. M., McMullen, J. S., Morse, E. A., \& Smith, J. B. (2007). The central question in entrepreneurial cognition research 2007. Entrepreneurship Theory and Practice, 31(1), 1-27.

Perry, J. T., Chandler, G. N., \& Markova, G. (2012). Entrepreneurial effectuation: A review and suggestions for future research. Entrepreneurship Theory and Practice, 36(4), 837-861.

Pham, L. B., \& Taylor, S. E. (1999). From thought to action: Effects of process-versus outcome-based mental simulations on performance. Personality and Social Psychology Bulletin, 25(2), 250-260.

Podoynitsyna, K., Van der Bij, H., \& Song, M. (2012). The role of mixed emotions in the risk perception of novice and serial entrepreneurs. Entrepreneurship Theory and Practice, 36(1), 115-140.

Ragin, C. C. (2000). Fuzzy-set social science. Chicago, IL: The University of Chicago Press.

Ragin, C. C. (2008). Qualitative comparative analysis using fuzzy sets (fsQCA). In R. Benoit, \& C. Ragin (Eds.). Configurational comparative analysis (pp. 87-121). Thousand Oaks, CA and London: Sage Publications.

Ragin, C. C., \& Davey, S. (2014). fs/QCA [computer programme], version [3.0]. Irvine, CA: University of California.

Read, S., \& Sarasvathy, S. D. (2005). Knowing what to do and doing what you know: Effectuation as a form of entrepreneurial expertise. The Journal of Private Equity, 9(1), $45-62$.

Read, S., Sarasvathy, S. D., Dew, N., \& Wiltbank, R. (2016). Response to Arend, Sarooghi, and Burkemper (2015): Cocreating effectual entrepreneurship research. Academy of Management Review, 41(3), 528-536.

Read, S., Song, M., \& Smit, W. (2009). A meta-analytic review of effectuation and venture performance. Journal of Business Venturing, 24(6), 573-587.

Reuber, A. R., Fischer, E., \& Coviello, N. (2016). Deepening the dialogue: New directions for the evolution of effectuation theory. Academy of Management Review, 41(3), $536-540$.

Reynolds, P. D., Bosma, N., Autio, E., Hunt, S., De Bono, N., Servais, I., ... Chin, N. (2005). Global entrepreneurship monitor. Data collection design and implementation 1998-2003. Small Business Economics, 24, 205-231.

Ross, L. W., \& Byrd, K. A. (2011). Business plan competitions: Start-up "idols" and their twenty-first century launch pads. Journal of Higher Education Theory and Practice, 11(4), 53-64.

Ryan, R. M., \& Deci, E. L. (2000). Self-determination theory and the facilitation of intrinsic motivation, social development, and well-being. American Psychologist, 55(1), 68-78.

Sarasvathy, S. D. (1998). How do firms come to be? Towards a theory of the prefirm. Dissertation. Carnegie Mellon University: Graduate School of Industria Administration.

Sarasvathy, S. (2008). Effectuation. London, UK: Edward Elgar.

Sarasvathy, S. D. (2001). Causation and effectuation: Toward a theoretical shift from economic inevitability to entrepreneurial contingency. Academy of Management
Review, 26(2), 243-263

Sarasvathy, S. D., \& Dew, N. (2005). New market creation through transformation. Journal of Evolutionary Economics, 15(5), 533-565.

Sarasvathy, S., \& Dew, N. (2008). Effectuation and over-trust: Debating Goel and Karri. Entrepreneurship Theory and Practice, 32, 727-737.

Schneider, M. R., Schulze-Bentrop, C., \& Paunescu, M. (2010). Mapping the institutional capital of high-tech firms: A fuzzy-set analysis of capitalist variety and export performance. Journal of International Business Studies, 41(2), 246-266.

Schoenfeld, A. H. (2011). How we think. New York, NY: Routledge.

Schwarz, N., \& Clore, G. L. (1996). Feelings and phenomenal experiences. In E. E. Higgins, \& A. Kruglanski (Eds.). Social psychology: Handbook of basic principles (pp. 385-407). New York, NY: Guilford Press.

Shane, S., \& Venkataraman, S. (2000). The promise of entrepreneurship as a field of research. Academy of Management Review, 25(1), 217-226.

Simon, M., Houghton, S. M., \& Aquino, K. (2000). Cognitive biases, risk perception, and venture formation: How individuals decide to start companies. Journal of Business

Venturing, 15(2), 113-134.

Sitkin, S. B., \& Weingart, L. R. (1995). Determinants of risky decision-making behavior: A test of the mediating role of risk perceptions and propensity. Academy of Management Journal, 38(6), 1573-1592.

Sitoh, M. K., Pan, S. L., \& Yu, C. Y. (2014). Business models and tactics in new product creation: The interplay of effectuation and causation processes. IEEE Transactions on Engineering Management, 61(2), 213-224.

Timmons, J., \& Spinelli, S. (2003). New venture creation: Entrepreneurship for the 21st century. New York: McGraw-Hill.

Thorgren, S., \& Wincent, J. (2013). Passion and challenging goals: Drawbacks of rushing into goal-setting processes. Journal of Applied Social Psychology, 43(11), 2318-2329.

Vallerand, R. J. (2008). On the psychology of passion: In search of what makes people's lives most worth living. Canadian Psychology/Psychologie Canadienne, 49(1), 1-13. Vallerand, R. J. (2010). On passion for life activities: The dualistic model of passion. Advances in Experimental Social Psychology, 42, 97-193.

Vallerand, R. J., Blanchard, C., Mageau, G. A., Koestner, R., Ratelle, C., Leonard, M., ... Marsolais, J. (2003). Les passions de l'ame: on obsessive and harmonious passion.

Journal of Personality and Social Psychology, 85(4), 756-767.

Vallerand, R. J., Salvy, S., Mageau, G. A., Elliot, A. J., Denis, P. L., Grouzet, F. M. E., \& Blanchard, C. (2007). On the role of passion in performance. Journal of Personality, $75,505-533$.

Wiltbank, R., Dew, N., Read, S., \& Sarasvathy, S. D. (2006). What to do next? The case for non-predictive strategy. Strategic Management Journal, 27(10), 981-998.

Wiltbank, R., Read, S., Dew, N., \& Sarasvathy, S. D. (2009). Prediction and control under uncertainty: Outcomes in angel investing. Journal of Business Venturing, 24(2), 116-133.

Wood, R., \& Bandura, A. (1989). Social cognitive theory of organizational management. Academy of Management Review, 14(3), 361-384.

Woodside, A. G. (2013). Moving beyond multiple regression analysis to algorithms: Calling for a paradigm shift from symmetric to asymmetric thinking in data analysis, and crafting theory. Journal of Business Research, 66, 463-472. 